\title{
Protective role of Ficus deltoidea against BPA-induced impairments of the follicular development, estrous cycle, gonadotropin and sex steroid hormones level of prepubertal rats
}

\author{
Siti Sarah Mohamad Zaid ${ }^{1 *}$, Shatrah Othman ${ }^{3}$ and Normadiah M. Kassim²
}

\begin{abstract}
Ficus deltoidea is one of the well-known medicinal plants in Malaysia that is traditionally used by the Malay community to treat various ailments and for maintenance of female reproductive health. The objective of this study is to evaluate the potential protective roles of Ficus deltoidea against BPA-induced toxicity of the pituitary-ovarian axis in pre-pubertal female rats. In this study, four groups of pre-pubertal female Sprague Dawley rats were administered with the followings by oral gavage for a period of six weeks: NC (negative control- treated with vehicle), PC (positive control-treated with BPA at $10 \mathrm{mg} /$ $\mathrm{kg} / \mathrm{BW}$ ), F (treated with Ficus deltoidea at $100 \mathrm{mg} / \mathrm{kg} / \mathrm{BW}$, then exposed to BPA at $10 \mathrm{mg} / \mathrm{kg} / \mathrm{BW}$ ) and FC (Ficus deltoidea control - treated with Ficus deltoidea at $100 \mathrm{mg} / \mathrm{kg} / \mathrm{BW}$ ). Daily vaginal smear, ovarian follicular development as well as gonadotropin and sexual-steroid hormone levels were determined. The findings showed that Ficus deltoidea demonstrated preventive role against BPA-induced toxicity on the ovaries. This was evident by the increased percentage of rats with normal estrous cycle, qualitatively reduced number of atretic follicles (as observed in histopathological examination) and normalization of the gonadotropins hormone (FSH) and sexual steroid hormone (progesterone) levels. In conclusion, Ficus deltoidea has the capability to prevent the effects of BPA toxicity in the hypothalamus-pituitary-gonadal axis of prepubertal female reproductive system, possibly due to its variety of phytochemical properties. Therefore, these findings strongly support the traditional belief that this medicinal plant is beneficial as daily dietary supplement for the maintenance of female reproductive health.
\end{abstract}

Keywords: Ficus deltoidea, BPA, Toxicity, Follicular, Estrous, Hormones, Ovary, Reproduction

\section{Introduction}

In recent years, exposure to environmental toxicants has become a serious health concern. Anxiety over exposure to endocrine disrupting chemicals (EDCs) in humans and wildlife has escalated since they have detrimental effects on the development and functions of the reproductive system $[1,2]$. One of the EDCs is the bisphenol A (BPA) that is widely used in the industries as plasticizer for the production of polycarbonate plastics and epoxy resins [3].

\footnotetext{
*Correspondence: mz_sarah@upm.edu.my; sarah_leo7@yahoo.com ${ }^{1}$ Department of Environmental Sciences, Faculty of Environmental Studies, Universiti Putra Malaysia, 43400 Serdang, Selangor, Malaysia Full list of author information is available at the end of the article
}

Process of reproduction in humans is tightly regulated by the hypothalamic-pituitary-gonadal axis (HPG) [4-6]. In the hypothalamus, secretion of gonadotropin releasing hormone $(\mathrm{GnRH})$ is crucial for the coordination of reproductive maturation and activity. Meanwhile, pituitary gonadotropin hormones, namely FSH and LH, are directly influenced by GnRH. Hence, disruptions in the normal pulsatile secretion of GnRH by BPA in the brain consequently alter the level of gonadotropins secretion [7]. In the ovary, BPA exposure is reported to have negative effects on the granulosa cell steroidogenesis [8-10], reduces the pool of primordial follicles [11], increases antral follicles and reduces the percentage of corpora lutea [12]. BPA also increases the risk for development

(c) The Author(s). 2018 Open Access This article is distributed under the terms of the Creative Commons Attribution 4.0 International License (http://creativecommons.org/licenses/by/4.0/), which permits unrestricted use, distribution, and reproduction in any medium, provided you give appropriate credit to the original author(s) and the source, provide a link to the Creative Commons license, and indicate if changes were made. The Creative Commons Public Domain Dedication waiver (http://creativecommons.org/publicdomain/zero/1.0/) applies to the data made available in this article, unless otherwise stated. 
of polycystic ovaries syndrome (PCOS) [13] and decreases the levels of luteinizing hormone (LH) and follicle stimulating hormone (FSH) levels [14].

For these reasons, BPA may predispose these organs to earlier onset of diseases, reduced fertility and even promote cancer. Apart from the xenoestrogenic properties, the disruptive effects of BPA in the brain have been shown to be mediated by reactive oxygen species (ROS) generation. It is believed that the generation of ROS by BPA leads to the increase in the level of lipid peroxidation product (MDA) [15] while reducing the level of antioxidant glutathione (GSH). Thus, with these concerns in mind, we propose to use a natural product with high antioxidant activities, namely the Ficus deltoidea, as a potential therapeutic role to counter the deleterious effects of BPA on the reproductive system.

Ficus deltoidea is one of the most well-known and available ficus species in Malaysia; it is traditionally used by Malay community for health maintenance purposes particularly in the maintenance of female reproductive system [16]. This medicinal plant is locally known as Mas Cotek due to the tiny golden spots on the leaves. Extensive pharmacological studies have validated the traditional use of Ficus deltoidea, particularly for maintenance and fertility of the female reproductive system [17]. Apart from its beneficial effects on female reproductive system, this medicinal plant has also been reported to have antidiabetic [18], anti-inflammatory and anti-nociceptive [19], anti-melanogenic and anti-photoaging [20], anti-bacterial [21], wound healing [22], anti-cancer and cytotoxicity properties [23].

In the present study, systematic analysis on investigating the potential protective roles of Ficus deltoidea against the toxicity effects of BPA on the female reproductive system was conducted. Prepubertal female rats were concurrently treated with Ficus deltoidea and BPA by oral gavage over a six-week period. The protective effects of Ficus deltoidea on the follicular development, gonadotropin (17 $\beta$-estradiol and progesterone) and sex steroid hormones (FSH and $\mathrm{LH}$ ) as well as on the pattern of the estrous cycle were determined.

\section{Material and methods}

\section{Animal and experimental design}

All the experimental design and procedures were conducted according to the National Institutes of Health guide for the care and use of laboratory animals (NIH Publications No. 8023, revised in 1978) and approved by the Animal Care and Committee (ACUC) of University of Malaya. Female Sprague Dawley rats at 21-day of age were purchased from the Animal Husbandry Unit, Faculty of Medicine, University of Malaya. The rats were maintained under the standard laboratory conditions at $25 \pm 2{ }^{\circ} \mathrm{C}, 50 \pm 15 \%$ relative humidity and normal photoperiod of $12 \mathrm{~h}$ dark and $12 \mathrm{~h}$ light. They were acclimatized to the laboratory environment for a week before the commencement of the experiments. Tap water and commercial pellet diet (Gold Coin Feedmills Pte. Ltd., Malaysia) were supplied ad libitum. To minimize additional exposures to endocrine disruptors, all rats were placed in stainless steel cages with wood bedding and water was supplied in glass bottles. At 28-day of age, the rats were divided into four groups $(n=8)$ and treated as follows:

1) NC group (negative control) was treated with vehicle $(0.2 \mathrm{ml}$ of corn oil).

2) PC group (positive control) was treated with BPA suspended in vehicle at $10 \mathrm{mg} / \mathrm{kg}$ body weight.

3) F group (Ficus deltoidea + BPA) was treated with $100 \mathrm{mg} / \mathrm{kg}$ body weight of Ficus deltoidea $30 \mathrm{~min}$ before they were treated with BPA $(10 \mathrm{mg} / \mathrm{kg}$ body weight).

4) FC group (Ficus deltoidea control) was treated with $100 \mathrm{mg} / \mathrm{kg}$ body weight of Ficus deltoidea.

The administration of the various treatment was performed once daily in the morning (between 09:00 and 10:00 AM) by oral gavage (to mimic the most likely route of human exposure) for six consecutive weeks. The daily body weight was recorded throughout the administration period. After the last treatment day, the rats were sacrificed during diestrous phase. Immediately, the weights of the ovaries were recorded, then ovaries were fixed in $10 \%$ buffered formalin for histopathological analysis.

\section{Aqueous extract of Ficus deltoidea (mas Cotek)}

The female leaves of this medicinal plant were purchased from Herba Bagus Sdn. Bhd, Malaysia. The leaves were then deposited at the Herbarium of the Institute of Bioproduct Development (IBD), Universiti Teknologi Malaysia (UTM), Johor, after they were authenticated by a licensed botanist (voucher specimen: MFD 6). The International Plant Names Index is Ficus deltoidea Jack (ID no.: 852727). For aqueous extraction preparation, $10 \mathrm{~kg}$ of leaves were boiled with $80 \mathrm{~L}$ of distilled water for two hours. Then, the extract was filtered and freeze-dried at $180{ }^{\circ} \mathrm{C}$ (inlet temperature) and $108{ }^{\circ} \mathrm{C}$ (outlet temperature). Finally, the aqueous extract of Ficus deltoidea was kept in an air-tight container and stored in a refrigerator at $4{ }^{\circ} \mathrm{C}$ until use.

The selection dose of $100 \mathrm{mg} / \mathrm{kg}$ body weight of aqueous extract of Ficus deltoidea was based on a previous subchronic toxicity study where no signs of toxicity effects were observed in hematological and biochemical parameters in rats [24]. Ficus deltoidea female leaves were selected due to its higher antioxidants levels compared to the male leaves (Fig. 1), in accordance with the 


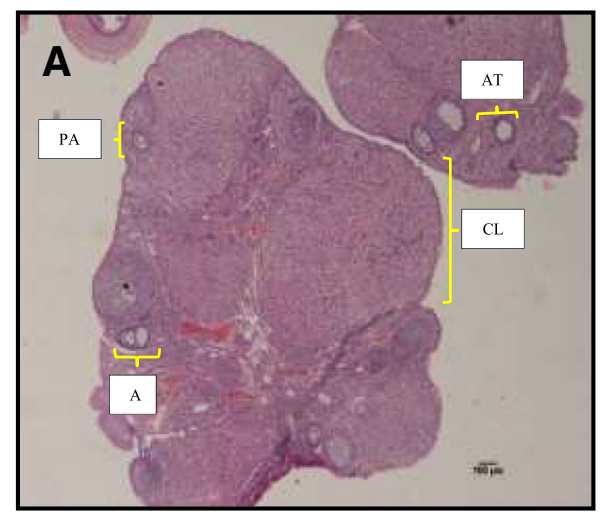

NC group

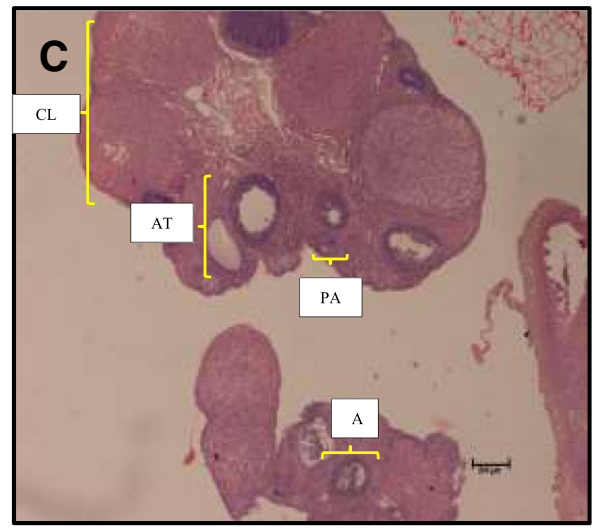

F group

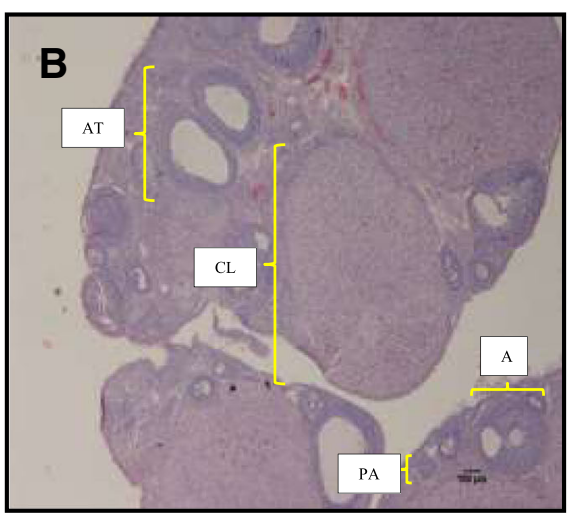

PC group

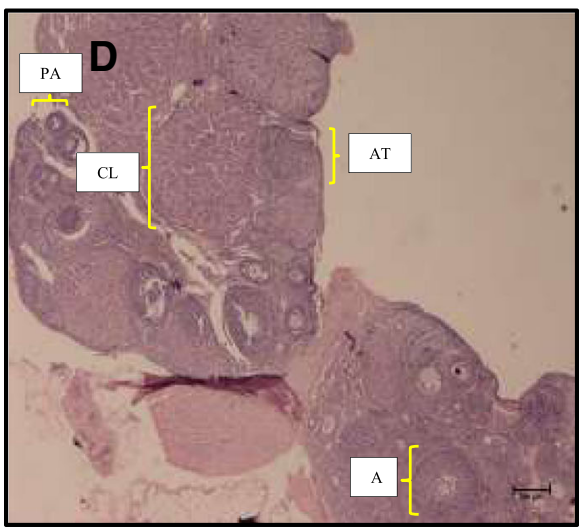

FC group

Fig. 1 Representative histological sections from ovary rat of all experimental groups (H\&E, 40X). a In NC group, normal histological appearance was observed. b More apparent atretic cystic-like follicles were observed in BPA-exposed rats (PC group). $\mathbf{c}$ Less atretic follicles were observed in BPA-exposed rats concurrently treated with Ficus deltoidea (F group). $\mathbf{d}$ The histological appearance in rats treated with Ficus deltoidea (FC group) was comparable to the control rats (FC group). PA: Preantral; A:Antral; At:Atretic; CL:Corpus Luteum. NC- Negative Control group (vehicle corn oil). PC- Positive Control group (BPA $10 \mathrm{mg} / \mathrm{kg}$ ). F-Ficus deltoidea group (Ficus deltoidea $100 \mathrm{mg} / \mathrm{kg}+$ BPA $10 \mathrm{mg} / \mathrm{kg}$ ). FC- Ficus deltoidea Control group (Ficus deltoidea $100 \mathrm{mg} / \mathrm{kg}$ )

non-enzymatic and enzymatic antioxidant assays [25]. The extract of the leaves has also been found to be more potent in cytotoxicity activity than the fruit extract [26]. The dose of BPA at $10 \mathrm{mg} / \mathrm{g}$ body weight was based on previous studies that induced disruption on morphological and biochemical parameters in the reproductive system [27-30].

\section{Estrous cycle assessment}

In the present study, the first day of daily vaginal smear was commenced once vaginal opening was detected in the rats (between 09:00 and 10:00 AM). For the collection of vaginal secretions, micropipette tips filled with approximately $0.2 \mathrm{ml}$ of normal saline $(\mathrm{NaCl} 0.9 \%)$ was inserted into vagina to a depth of 2 to $5 \mathrm{~mm}$. Normal saline was used as an isotonic solution with osmolarity closed to the blood that provide longer period for the cells from lysis. Then, the normal saline was flushed repeatedly into the micropipette tips for three times before the vaginal secretion sample was collected. A drop of suspension was smeared onto a labeled glass slide and immediately viewed under a light microscope, using objective lenses $\times 10$ and $\times 40$ (for determination of proportion the three cell types and characterization of dominant cells, respectively). Cytological appearance of estrous phase was determined as follows:

1) The proestrous phase (twelve to fourteen hours) consists of predominance of nucleated epithelial cells.

2) An estrous phase (twenty-five to twenty-seven hours) primarily consists of anucleated cornified cells.

3) An metestrous phase (six to eight hours) indicated by equal proportions of leucocytes, anucleated cornified and nucleated epithelial cells. 
4) The diestrous phase (fifty-five to fifty-seven hours) primarily consists of predominance of leucocytes.

The estrous cycle patterns are described as follows:

1) Normal cycle: A 4 to 5-day of estrous cycle in which the estrous phase was observed at least twice during the sampling period.

2) Persistent diestrous: or prolonged diestrous that lasts 4 or more days of diestrous phase during most of the cycle.

\section{Histopathological evaluation}

The formalin-fixed ovary was processed by dehydration in a graded series of ethanol, cleared by xylene and infiltrated in paraffin using an automatic tissue processor (Citadel 2000, Thermo-Scientific, USA). Subsequently, these processed tissue was embedded in paraffin. The ovary paraffin block was serially sectioned at $5 \mu \mathrm{m}$ thickness, mounted onto labeled glass slides, deparaffinized in xylene, stained with hematoxylin and eosin (Sigma Aldrich, USA), and finally dehydrated in a graded series of ethanol, cleared in xylene and mounted with Canada Balsam (Sigma-Aldrich, USA).

\section{Classification and quantification of ovarian follicles}

Classification and quantification of ovarian follicles were performed on 62 total field areas and measured with grid lines using NIS-elements software as described by Zhuang et al. [31]. One section was chosen out of every 20 sections with five sections collected from each ovary. Each of selected ovarian sections were traced around the tissue boundaries with the computerized software and a sampling grid is superimposed over the section. The standardized size of counting fields were manually traced on the gridlines

A) A primary follicle comprises an oocyte surrounded by a single layer of cuboidal granulosa cells while a secondary follicle consists of an oocyte surrounded by more than one layer of cuboidal granulosa cells and no visible antrum.

B) An antral follicle has a clearly defined antral space and cumulus granulosa cell layer.

C) The corpus luteum is comprised of lutein cells and formed only after ovulation.

D) An atretic follicle is a degenerated follicle with inspissated follicular fluid, degenerated oocyte, disorganized and thickened granulosa cell layers or filled with fibrinous material in the antrum.

Serum FSH, LH, $17 \beta$-estradiol and progesterone assay Measurement of these hormone levels were performed using ELISA based kits (Cusabio, USA) following similar principal and protocols. Each hormone was analyzed using different kits according to the specific Antibody and Horseradish Peroxidase.

In brief, $50 \mu \mathrm{l}$ duplicates of standards, samples and blank were added to the representative wells coated with $\mathrm{E}_{2}$. Subsequently, $50 \mu \mathrm{l}$ of specific HRP conjugate were added to each well (except to blank wells). Then, $50 \mu \mathrm{l}$ of specific antibody for each hormone was added to each well. The solutions in the wells were mixed and incubated for two hours in a $37{ }^{\circ} \mathrm{C}$ incubator (Echo Thermo, USA). After the incubation period, these mixed solutions were carefully aspirated from each well and the wells were rinsed three times using Wash Buffer solutions. Subsequently, $50 \mu \mathrm{l}$ of the Substrate A and Substrate B supplied in the kit were added to each well and incubated again for another $15 \mathrm{~min}$ at $37^{\circ} \mathrm{C}$.

Finally, the reactions were terminated using $50 \mu \mathrm{l}$ of Stop Solution. A microplate reader (BioTek, USA) was used to measure the optical density (OD) at wavelength of $450 \mathrm{~nm}$. A standard curve was constructed by plotting a graph of the absorbance of each reference standard against its corresponding level and used to determine each hormone level.

\section{Statistical analysis}

All statistical analysis was performed used Statistical Package for Social Sciences (SPSS Inc. Chicago, Illinois, USA version 18.0 for windows). Results were analyzed using two-way analysis of variance (ANOVA). Values are reported as mean \pm S.E.M. $P<0.05$ was considered significant.

\section{Results}

Estrous cycle

As shown in Table 1, all rats in the NC and FC groups had normal estrous cycles (100\%). However, for BPA-exposed rats (PC group) only $12.5 \%$ had normal estrous cycles, while majority of rats were in persistent diestrous phase; these estrous cycle patterns were

Table 1 Effect of BPA and Ficus deltoidea on the estrous cycle $(n=8)$

\begin{tabular}{ll}
\hline Group & $\begin{array}{l}\text { Rat with normal estrous } \\
\text { cycle, } \mathrm{n}(100 \%)\end{array}$ \\
\hline NC & $8 / 8(100 \%)$ \\
PC & $1 / 8^{\mathrm{a}}(12.5 \%)$ \\
F & $5 / 8^{\mathrm{b}}(62.5 \%)$ \\
FC & $8 / 8(100 \%)$
\end{tabular}

Data are expressed as Mean \pm SEM

NC vs. $P C={ }^{a}$

$\mathrm{PC}$ vs. $\mathrm{F}={ }^{\mathrm{b}}$

NC Negative Control group (vehicle corn oil)

PC Positive Control group (BPA $10 \mathrm{mg} / \mathrm{kg}$ )

F Ficus deltoidea group (Ficus deltoidea $100 \mathrm{mg} / \mathrm{kg}$ + BPA $10 \mathrm{mg} / \mathrm{kg}$ )

FC Ficus deltoidea Control group (Ficus deltoidea $100 \mathrm{mg} / \mathrm{kg}$ ) 
significantly different compared to the $\mathrm{NC}$ and $\mathrm{PC}$ groups. In BPA-exposed rats concurrently treated with Ficus deltoidea showed better percentage of rats with normal estrous cycles $(62.5 \%)$ and a reduction of rats in persistent diestrous phase compared to BPA-exposed rats without treatment ( $\mathrm{PC}$ group).

\section{Body weight and organ weight}

A slightly increment of body weight gain was observed in rats exposed to BPA (PC group) compared to the control rats (NC group) as shown in Table 2. Meanwhile, the body weight gain of rats treated with Ficus deltoidea alone (FC group) were comparable to those of the control rats (NC group).

As depicted in Table 2, rats exposed to BPA showed significantly higher relative ovary weight compared to the control rats (NC group). This increment was significantly prevented by concurrent treatment with Ficus deltoidea ( $\mathrm{F}$ group). The relative ovary weight in rats treated with Ficus deltoidea alone (FC group) was slightly lower but not significantly different when compared to the control rat (NC group).

\section{Hormonal profiles}

As shown in Table 3, serum FSH and LH levels were significantly reduced in BPA-exposed rats (PC groups) compared to the control rats (NC group). Meanwhile, in BPA-exposed rats concurrently treated with Ficus deltoidea had significantly higher FSH levels. On the other hand, reduction of LH level in BPA-exposed rats was not significantly prevented by Ficus deltoidea treatment. Both these hormonal levels were comparable in rats from $\mathrm{FC}$ and $\mathrm{NC}$ groups.

In BPA-exposed rats (PC group), the level of $\mathrm{E}_{2}$ was slightly higher than the control rats (NC group). Comparable increment of $E_{2}$ level was observed in BPA-exposed rats concurrently treated with Ficus deltoidea (F group) but at a lower magnitude compared to the rats exposed to BPA alone. $E_{2}$ level in rats treated with
Ficus deltoidea alone (FC group) was comparable to the normal control rats (NC rats).

Progesterone level in BPA-exposed rats was significantly lower compared to the control rats (NC group). However, progesterone level in BPA-exposed rats concurrently treated with Ficus deltoidea was significantly reduced. Meanwhile, the progesterone level in Ficus deltoidea treated rats was comparable to the normal control rats (NC group).

\section{Ovarian follicular counting}

As depicted in Fig. 1, all stages of follicular development that consisted of preantral, antral, corpus luteum and atretic follicles were present in the ovaries of rats from all experimental groups. Control (NC group) and Ficus deltoidea treated alone (FC group) rats showed normal histological characteristics of ovaries. As for the PC and F groups, different histological findings were noted. Histological abnormalities of the ovaries include large antral-like follicle and atretic cystic-like follicles that did not reach ovulation stage. Accordingly, less number of corpora lutea were found in both groups as a result of reduced follicles reach ovulation stage. The degree of abnormalities was more apparent in the ovaries of BPA-exposed rats alone (PC group) compared to the BPA-exposed rats concurrently treated with Ficus deltoidea (F group).

Further quantitative analysis of the follicular number in all ovaries from all experimental groups were conducted to determine the degree of these ovarian histological derangement (Fig. 2). In general, consistent results of the ovarian histological changes and follicular counts were observed. Control (NC group) and Ficus deltoidea treated alone (FC) rats have shown comparable morphology of all the ovarian follicles (preantal, antral, corpus luteum and atretic follicles) with the histological findings of normal ovaries.

Disruptive histological changes in rats from PC group were consistent with the follicular count. In BPA-exposed rats (PC group), the number of atretic

Table 2 Effect of BPA and Ficus deltoidea on body weight and weights of ovary of rats $(n=8)$

\begin{tabular}{llllll}
\hline Group & $\begin{array}{l}\text { Body weight } \\
\text { at sacrifice }(\mathrm{g})\end{array}$ & $\begin{array}{l}\text { Body weight } \\
\text { gain }(\mathrm{g})\end{array}$ & $\begin{array}{l}\text { Changes in body } \\
\text { weight gain (\%) }\end{array}$ & $\begin{array}{l}\text { Ovarian wet } \\
\text { weight (mg) }\end{array}$ & $\begin{array}{l}\text { Relative weight of ovary } \\
\text { (wet weight/body weight) }\end{array}$ \\
\hline NC & $260.22 \pm 6.61$ & $78.88 \pm 4.61$ & $48.15 \pm 2.60$ & $36.88 \pm 1.88$ & $0.24 \pm 0.01$ \\
PC & $287.31 \pm 5.90$ & $99.25 \pm 3.90$ & $56.52 \pm 3.49$ & $49.38 \pm 1.13$ & $0.29 \pm 0.01^{\mathrm{a}}$ \\
F & $280.29 \pm 4.62$ & $92.50 \pm 2.62$ & $56.12 \pm 1.94$ & $35.00 \pm 1.34$ & $0.21 \pm 0.01^{\mathrm{b}}$ \\
FC & $272.89 \pm 4.64$ & $89.50 \pm 2.64$ & $52.39 \pm 3.47$ & $33.13 \pm 2.49$ & $0.20 \pm 0.02$ \\
\hline
\end{tabular}

Data are expressed as Mean \pm SEM

NC vs. PC $=^{a}$

$P C$ vs. $F={ }^{b}$

NC Negative Control group (vehicle corn oil)

PC Positive Control group (BPA $10 \mathrm{mg} / \mathrm{kg}$ )

F Ficus deltoidea group (Ficus deltoidea $100 \mathrm{mg} / \mathrm{kg}+$ BPA $10 \mathrm{mg} / \mathrm{kg}$ )

FC Ficus deltoidea Control group (Ficus deltoidea $100 \mathrm{mg} / \mathrm{kg}$ ) 
Table 3 Level of reproductive hormones in all experimental groups $(n=8)$

\begin{tabular}{lllll}
\hline Group & $\begin{array}{l}\text { Follicle Stimulating Hormone } \\
(\mathrm{FSH})(\mathrm{mlU} / \mathrm{ml})\end{array}$ & $\begin{array}{l}\text { Luteinizing Hormone } \\
(\mathrm{LH})(\mathrm{mlU} / \mathrm{ml})\end{array}$ & $\begin{array}{l}17 \beta \text {-Estradiol } \\
(\mathrm{pg} / \mathrm{ml})\end{array}$ & $\begin{array}{l}\text { Progesterone } \\
(\mathrm{ng} / \mathrm{ml})\end{array}$ \\
\hline NC & $78.50 \pm 4.96$ & $10.25 \pm 2.71$ & $19.04 \pm 3.99$ & $64.65 \pm 3.28$ \\
PC & $31.25 \pm 5.96^{\mathrm{a}}$ & $1.99 \pm 0.32^{\mathrm{a}}$ & $24.46 \pm 2.22$ & $34.95 \pm 4.56^{\mathrm{a}}$ \\
F & $52.87 \pm 2.34^{\mathrm{b}}$ & $1.91 \pm 0.12$ & $22.42 \pm 2.07$ & $42.78 \pm 3.36^{\mathrm{b}}$ \\
FC & $72.00 \pm 7.25$ & $9.30 \pm 1.19$ & $21.42 \pm 1.62$ & $52.16 \pm 4.57$ \\
\hline
\end{tabular}

Data are expressed as Mean \pm SEM

NC vs. $P C={ }^{a}$

$P C$ vs. $F={ }^{b}$

NC Negative Control group (vehicle corn oil)

PC Positive Control group (BPA $10 \mathrm{mg} / \mathrm{kg}$ )

F Ficus deltoidea group (Ficus deltoidea $100 \mathrm{mg} / \mathrm{kg}+$ BPA $10 \mathrm{mg} / \mathrm{kg}$ )

FC Ficus deltoidea Control group (Ficus deltoidea $100 \mathrm{mg} / \mathrm{kg}$ )

follicles was significantly higher compared to the control rats (NC group). Even not statistically significant, there were slightly lesser atretic follicle count in BPA-exposed rats concurrently treated with Ficus deltoidea (F group). The higher number of atretic follicles in BPA-exposed rats could be related to the histological findings where more apparent atretic cystic-like follicles were observed compared to the rats concurrently treated with Ficus deltoidea and BPA (F group).

\section{Discussion}

BPA is one of the EDCs that is reported to induce weight gain in rodent models $[31,32]$. In the present study, the mean body weight of BPA-exposed rats were slight increased, but was not significantly different compared to the control rats. This suggests that BPA may not be directly correlated with weight gain and this is in agreement with previous reports [33-35]. A study by Kwon et al [33] found that oral administration of BPA at high doses had no effect on the body weight of rats. Similar findings from another study also reported no difference in the body weight of rat offspring that were perinatally-exposed to low doses of BPA [36]. In fact, the discrepancy in the findings of body weight changes remain enigmatic and could be due to many factors such as differences in the sensitivity of the strain used, dose, route of exposure, window of exposure (age) and duration of exposure [37-39].

Many studies have reported on the disruptive effects of BPA on the estrous cycle of rats [9, 33, 40,41]. Our findings were in agreement with these reports that the duration of estrous cycle was prolonged (more than 4 or 5 days) in BPA-exposed rats compared to the control rats. This was likely due to the long diestrous phase as shown in our results. The disruption of estrous cycle in BPA-exposed rats could be due to the alteration in the normal functions of the hypothalamic-pituitary axis, which interfered with the normal production of gonadotropin releasing hormone (GnRH) and thereby decreasing the secretion of FSH and LH levels. The interference by BPA on the production of gonadotropin hormones (FSH and $\mathrm{LH}$ ) could affect the gonadal function, which

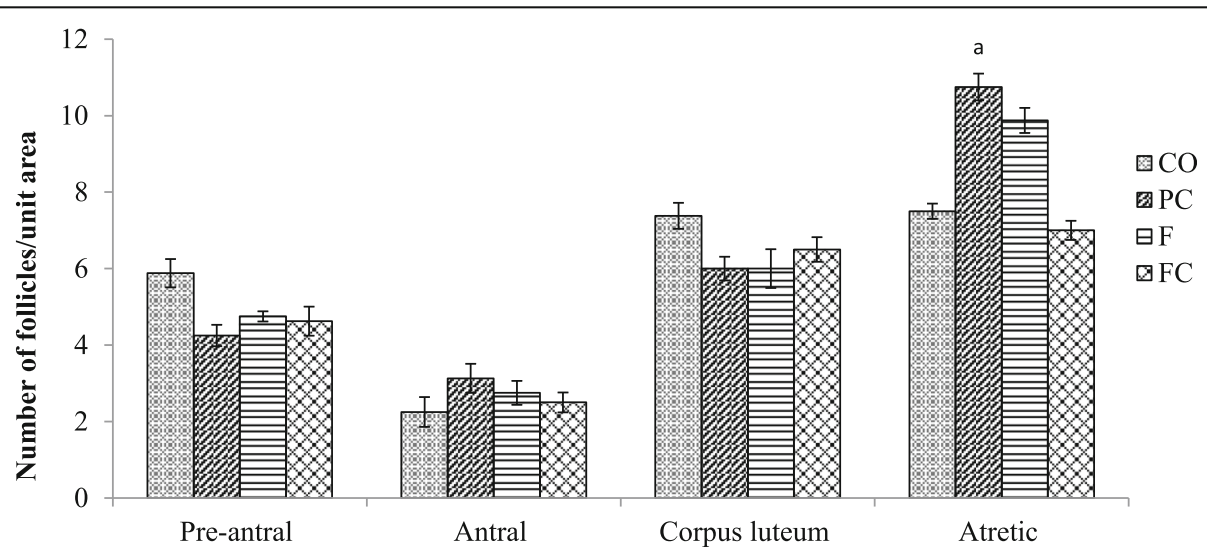

Fig. 2 Number of follicles in all experimental groups. In BPA-exposed rats (PC group), the number of atretic follicles was significantly higher compared to the control rats (NC group). Ficus deltoidea was concurrently treated in the BPA-exposed rats (F group) and slight reduction was observed the number of atretic follicles compared to the BPA-exposed to Ficus deltoidea alone. Data are expressed as Mean \pm SEM. 1) ${ }^{\mathrm{a}} \mathrm{P}<0.05$ vs. NC. 2 ) ${ }^{\mathrm{b}} \mathrm{P}<0.05$ and ${ }^{\mathrm{bb}} \mathrm{P}<0.01 \mathrm{vs}$. PC. 3) ${ }^{d} P<0.05$ and ${ }^{d d} p<0.01$ vs. FC. NC- Negative Control group (vehicle corn oil). PC- Positive Control group (BPA $10 \mathrm{mg} / \mathrm{kg}$ ). F-Ficus deltoidea group (Ficus deltoidea $100 \mathrm{mg} / \mathrm{kg}$ + BPA $10 \mathrm{mg} / \mathrm{kg}$ ). FC- Ficus deltoidea Control group (Ficus deltoidea $100 \mathrm{mg} / \mathrm{kg}$ ) 
consequently disrupts the production of sexual steroid hormones, namely $E_{2}$ and progesterone from the ovary.

Concurrent treatment with Ficus deltoidea of BPA-exposed rats had resulted in significant increase in the percentage of rats with normal estrous cycle up to $62.5 \%$. Theoretically, the increase in the percentage of normal estrous cycle in BPA-exposed rat should essentially be related to the hypothalamic-pituitary axis, where normalization of gonadotropins hormone levels ought to be apparent. Improvement in the percentage of normal estrous cycle could be associated with reduced harmful effects of BPA on the ovarian follicular development in BPA-exposed rats. However, in this case, the increase in the percentage of normal estrous cycle in BPA-exposed rats is only accompanied by an increase in the level of FSH but not $\mathrm{LH}$, and the reasons for these remain enigmatic. It may be possible that Ficus deltoidea may not be affecting the pituitary, but acting primarily on the ovaries instead. They could be displaying their effects through estrogenic mechanisms via ERs at the ovaries, hence protecting the process of follicular development and ovulation. As we have shown, even with reduced LH level, ovulation still occurs as evidenced by the restoration of progesterone level secreted by corpus luteum in Ficus deltoidea-treated rats. Therefore, further investigation is warranted to define the mechanism that may be responsible to restore the normal estrous cycle in BPA-exposed rats treated with Ficus deltoidea without significantly affecting the hypothalamic-pituitary functions.

The ovary is the main target organs for xenoestrogenic compounds as proven in many scientific studies $[13,42$, $43,44]$. In the present study, the weight of ovary of BPA-exposed rats was increased by $20 \%$ compared to the control rats. Based to this result, it appears that BPA has some influence on the weight of ovary, without having significant effects on the body weight. This finding supports a previous report by Ashby et al. [45]. In fact, any changes of $10 \%$ or greater in the organ weight is a strong indicator of toxic effects, particularly when it is associated with morphological changes. In this study, the significant changes in the organ weight and size of ovary of BPA-exposed rats were in fact coupled with the overall disruptive effects by BPA.

In contrast to the normal histology of the normal ovary of the control rats, the presence of large-antral and atretic-cystic like follicles in BPA-exposed rats were evident. These abnormal follicles reflected the pathological alteration in the secretion of gonadotropins hormone (decreasing levels of FSH) and possibly account for the increase in the ovarian weight.

Reduction in the LH level observed in the BPAexposed rats may be the reason for the formation of cystic follicles (anovulatory follicles) and consequently reduction in the formation of corpora lutea in the ovary (formed after ovulation). When the formation of corpora lutea is reduced, the secretion of progesterone is low. Meanwhile, the increase number of cystic antral- like follicles with reduced corpora lutea in BPA-exposed rats in this study agrees with previous findings $[9,46]$. Cystic follicles are large antral-like follicles surrounded by thin layer of granulosa cells with non-detectable theca cell layers that do not support ovulation process in the ovary $[47,48]$. Interference with the normal development of follicles in the ovary was evidenced by reduction in the number of preantral follicles and increase in the number of atretic cystic-like follicles in BPA-exposed rats. Interestingly, changes in the follicular populations and histology in the ovary of BPA-exposed rats were similar to those seen in aging rats [49].

Changes in the relative ovarian weight of BPA-exposed rats were prevented by Ficus deltoidea treatments. The increase in ovarian weight, respectively, were normalized to the control levels. These suggest that Ficus deltoidea has the protective properties that prevent weight changes of the reproductive organ. Subsequently, further investigation showed that normalization of this organ weight by Ficus deltoidea was also correlated with the improvement of their morphology where the follicles were seen relatively healthier. These suggest the protective effects of Ficus deltoidea against the disruptive effects of BPA on the cellular components/level of the reproductive organ. The histological findings of ovaries rats treated with Ficus deltoidea alone or to the control rats, indicates that Ficus deltoidea has no pathological effects on this cellular organ. Although the morphological improvements in ovary were seen to be significant in BPA-exposed rats treated with Ficus deltoidea, the protection exerted by this medicinal plant seemed to be only partial compared to the control rats. This could be due to the incomplete elimination of ROS, thus enabling continual disruption on the cellular components and follicles. Moreover, even after elimination of ROS and BPA, the proteins/enzymes involved in the intracellular protective machinery may require a longer period of time to recover from the oxidative damage that has occurred [50]. Further analysis on this is therefore warranted.

\section{Conclusions}

In the present study, we demonstrated significant protective effects of Ficus deltoidea against the toxicity caused by BPA in the reproductive system. This medicinal plant has the capabilities to prevent toxicity effects of BPA as shown by the increase in the percentage of rats with normal estrous cycle, increase in the level of gonadotropins hormone (FSH) and sexual steroid hormone (progesterone) as well as reduction in the formation of the atretic follicles (qualitatively observed under the histopathological examination). 
The current findings strongly support the traditional belief that herbal plants are important as daily supplements in the diet for the promotion of long term reproductive health and fertility. In conclusion, Ficus deltoidea are able to prevent the toxicity effects of BPA on the prepubertal female reproductive system, possibly due to their variety of phytochemical properties. Hence, they may be particularly beneficial as health supplements to help in reducing the risk of permanent female reproductive infertility caused by prolonged BPA exposure, especially during their prepubertal period of life.

\section{Abbreviations}

BPA: Bisphenol A; EDCs: Endocrine disrupting chemicals; F: Ficus + BPA group; FC: Ficus group; FSH: Follicle stimulating hormone; GnRH: Gonadotropin releasing hormone; GSH: Gluthione; HPG: Hypothalamic-pituitary-gonadal axis: LH: Luteinizing hormone; MDA: Malondialdehyde; NC: Control group; OD: Optical density; PC: BPA-exposed group; PCOS: Polycyctic ovaries syndrome; ROS: Reactive oxygen species

\section{Acknowledgements}

The authors would like to acknowledge University of Malaya for providing a postgraduate research grant (No: PG087-2012B), Universiti Putra Malaysia for tutorship allowances and Scholarship Division, Ministry of Higher Education for their financial assistance to the first author Siti Sarah Mohamad Zaid. Sincere thanks to all staff of the Department of Anatomy and Department of Molecular Medicine, Faculty of Medicine, University of Malaya for their direct or indirect support towards the success of this project.

\section{Funding}

This project was funded by the Postgraduate research Grant (PG087-2012B).

\section{Availability of data and materials}

All data generated, analysed and reported in this published article.

\section{Authors' contributions}

SMZ, conceived the study, executed the experiments, generated and analyzed data, and produced a first draft of the manuscript. SO, approved the final manuscript. NMK, supervised, guided and approved the study. All authors read and approved the final manuscript.

\section{Ethics approval and consent to participate}

All animal procedures were approved by the Animal Care and Use Committee (ACUC) of University of Malaya [ANA/27/07/2014/SSMZ (R)].

\section{Consent for publication}

Concerned permission from Universiti Putra Malaysia and Universiti Malaya were obtained prior to submission of manuscript.

\section{Competing interests}

The authors declare that they have no competing interests.

\section{Publisher's Note}

Springer Nature remains neutral with regard to jurisdictional claims in published maps and institutional affiliations.

\section{Author details}

'Department of Environmental Sciences, Faculty of Environmental Studies, Universiti Putra Malaysia, 43400 Serdang, Selangor, Malaysia. ${ }^{2}$ Department of Anatomy, University of Malaya, 50603 Kuala Lumpur, Malaysia. ${ }^{3}$ Department of Molecular Medicine, Faculty of Medicine, University of Malaya, 50603 Kuala Lumpur, Malaysia.
Received: 21 August 2018 Accepted: 25 October 2018

Published online: 26 November 2018

\section{References}

1. Wetherill YB, Akingbemi BT, Kanno J, McLachlan JA, Nadal A, Sonnenschein C, Watson CS, Zoeller RT, Belcher SM. In vitro molecular mechanisms of bisphenol a action. Reprod Toxicol. 2007;24:178-98.

2. Ibtihaq FEG, Anisa EM, Eman FF, Amany S. Histological study of the possible protective effect of pomegranate juice on bisphenol-a induced of the caput epididymal epithelium and sperms of adult albino rats. Alexandria J Med. 2011:47:125-37

3. Von Goetz N, Wormuth M, Scheringer M, Hungerbuhler K. Bisphenol a: how the most relevant exposure sources contribute to total consumer exposure. Risk Anal. 2010;30:473-87.

4. Gamez JM, Penalba R, Cardoso N, Bernasconi P, Carbone S, Ponzo O, Pandolfi M, Scacchi P, Reynoso R. Exposure to a low dose of bisphenol a impairs pituitary-ovarian axis in prepubertal rats: effects on early folliculogenesis. Environ Toxicol Pharmacol. 2015;39:9-15.

5. Zaid SS, Sulaiman SA, Sirajudeen KN, Othman NH. The effects of Tualang honey on female reproductive organs, tibia bone and hormonal profile in ovariectomised rats-animal model for menopause. BMC Complement Altern Med. 2010;10:82

6. Zaid SS, Sulaiman SA, Othman NH, Soelaiman IN, Shuid AN, Mohamad N, Muhamad N. Protective effects of Tualang honey on bone structure in experimental postmenopausal rats. Clinics (Sao Paulo). 2012;67:779-84

7. Elkind-Hirsch K, King JC, Gerall AA, Arimura AA. The luteinizing hormonereleasing hormone $(\mathrm{LHRH})$ system in normal and estrogenized neonatal rats. Brain Res Bull. 1981;7:645-54

8. Biles JE, McNeal TP, Begley TH. Determination of bisphenol a migrating from epoxy can coatings to infant formula liquid concentrates. J Agric Food Chem. 1997:45:4691-700

9. Markey CM, Coombs MA, Sonnenschein C, Soto AM. Mammalian development in a changing environment: exposure to endocrine disruptors reveals the developmental plasticity of steroid-hormone target organs. Evol Dev. 2003:5:567-75.

10. Zaid SS, Othman S, Kassim NM. Potential protective effect of Tualang honey on BPA-induced ovarian toxicity in pepubertal rat. BMC Complement Altern Med. 2014;14:509

11. Takeuchi T, Tsutsumi O. Serum bisphenol a concentrations showed gender differences, possibly linked to androgen levels. Biochem Biophys Res Commun. 2002;291:76-8

12. Takeuchi T, Tsutsumi O, Ikezuki Y, Takai Y, Taketani Y. Positive relationship between androgen and the endocrine disruptor, bisphenol $a$, in normal women and women with ovarian dysfunction. Endocr J. 2004:51:165-9.

13. Xu J, Osuga Y, Yano T, Morita Y, Tang X, Fujiwara T, Takai Y, Matsumi H, Koga K, Taketani Y, Tsutsumi O. Bisphenol a induces apoptosis and G2-to-M arrest of ovarian granulosa cells. Biochem Biophys Res Commun. 2002;292:456-62.

14. Lee MS, Hyun SH, Lee CK, Im KS, Hwang IT, Lee HJ. Impact of xenoestrogens on the growth of human endometrial epithelial cells in a primary culture system. Fertil Steril. 2003;79:1464-5.

15. Zaid SS, Kassim NM, Othman S. Tualang honey protects against BPAinduced morphological abnormalities and disruption of ERa, ERß and C3 mRNA and protein expressions in the uterus of rats. E-CAM. 2015; 202874:1-18.

16. Bunawan H, Amin NM, Bunawan SN, Baharum SN, Mohd Noor N. Ficus deltoidea Jack: a review on its phytochemical and pharmacological importance. Evid Based Complement Alternat Med. 2014:2014:902734.

17. Salleh N, Ahmad VN. In-vitro effect of Ficus deltoidea on the contraction of isolated rat's uteri is mediated via multiple receptors binding and is dependent on extracellular calcium. BMC Complement Altern Med. 2013;133:59.

18. Kalman DS, Schwartz HI, Feldman S, Krieger DR. Efficacy and safety of Elaeis guineensis and Ficus deltoidea leaf extracts in adults with pre-diabetes. Nutr J. 2013;12:36.

19. Sulaiman MR, Hussain MK, Zakaria ZA, Somchit MN, Moin S, Mohamad AS, Israf DA. Evaluation of the antinociceptive activity of Ficus deltoidea aqueous extract. Fitoterapia. 2008;79:557-61.

20. Oh MJ, Hamid MA, Ngadiran S, Seo YK, Sarmidi MR, Park CS. Ficus deltoidea (mas cotek) extract exerted anti-melanogenic activity by preventing tyrosinase activity in vitro and by suppressing tyrosinase gene expression in B16F1 melanoma cells. Arch Dermatol Res. 2010;303:161-70. 
21. Samah OA, Zaidi NTA, Sule AB. Antimicrobial activity of Ficus deltoidea jack (mas cotek). Pak J Pharm Sci. 2012;25:25675-8.

22. Abdalla MA, Ahmed KAA, Abu-Luhoom FM, Muhanid M. Role of Ficus deltoidea extract in the enhancement of wound healing in experimental rats. Biomed Res. 2010;21:241-5.

23. Farsi E, Shafaei A, Hor SY, Ahamed MB, Yam MF, Asmawi MZ, Ismail Z. Genotoxicity and acute and subchronic toxicity studies of a standardized methanolic extract of Ficus deltoidea leaves. Clinics (Sao Paulo). 2013;68:865-75.

24. Fazliana MSH, Muhajir H, Hazilawati K, Shafii M, Mazleha M. Effects of Ficus deltoidea aqueous extract on hematological and biochemical parameters in rats. Med J Malaysia. 2008;63:103-4.

25. Hakiman M, Mahmood M. Non-enzymatic and enzymatic antioxidant activities in aqueos extract ficus deltoidea accessions. J Med Plants Res. 2009:3:120-31.

26. Norrizah JS, Norizan A, Sharipah Ruzaina SA, Dzulsuhaimi D, Nurul Hidayah MS. Cytoxicity activity and reproductive profiles of male rats treated with methanolic extracts of ficus deltoidea. Res J Med Plants. 2012;6:197-202.

27. Suzuki A, Sugihara A, Uchida K, Sato T, Ohta Y, Katsu Y, Watanabe H, Iguch T. Developmental effects of perinatal exposure to bisphenol-a and diethylstilbestrol on reproductive organs in female mice. Reprod Toxicol. 2002;16:107-16.

28. Okuda K, Takiguchi M, Yoshihara S. In vivo estrogenic potential of 4-methyl2,4-bis (4-hydroxyphenyl) pent-1-ene, an active metabolite of bisphenol a, in uterus of ovariectomized rat. Toxicol Lett. 2010;197:7-11.

29. Anjum S, Rahman S, Kaur M, Ahmad F, Rashid H, Ansari RA, Raisuddin S. Melatonin ameliorates bisphenol A-induced biochemical toxicity in testicular mitochondria of mouse. Food Chem Toxicol. 2011;49:2849-54.

30. Li Y, Zhang W, Liu J, Wang W, Li H, Zhu J, Weng S, Xiao S, Wu T. Prepubertal bisphenol a exposure interferes with ovarian follicle development and its relevant gene expression. Reprod Toxicol. 2013;44:33-40.

31. Zhuang XL, Fu YC, Kong XX, Cheng ZG, Luo LL. Effects of geneistein on ovarian follicular development and ovarian life span in rats. Fitoterapia. 2010;81:998-1002

32. Howdeshell KL, Hotchkiss AK, Thayer KA, Vandenbergh JG, Vom Saal FS. Exposure to bisphenol a advances puberty. Nature. 1999;401:763-4.

33. Kwon S, Stedman DB, Elswick BA, Cattley RC, Welsch F. Pubertal development and reproductive functions of $\mathrm{Crl}: \mathrm{CD}$ BR Sprague-Dawley rats exposed to bisphenol a during prenatal and postnatal development. Toxicol Sci. 2000;55:399-406

34. Tinwell H, Haseman J, Lefevre PA, Wallis N, Ashby J. Normal sexual development of two strains of rat exposed in utero to low doses of bisphenol a. Toxicol Sci. 2002;68:339-48.

35. Tan BL, Ali Mohd M. Analysis of selected pesticides and alkylphenols in human cord blood by gas chromatograph-mass spectrometer. Talanta. 2003;61:385-91.

36. Rubin BS, Murray MK, Damassa DA, King JC, Soto AM. Perinatal exposure to low doses of bisphenol a affects body weight, patterns of estrous cyclicity, and plasma LH levels. Environ Health Perspect. 2001;9:675-80.

37. Steinmetz R, Mitchner NA, Grant A, Allen DL, Bigsby RM, Ben-Jonathan N. The xenoestrogen bisphenol a induces growth, differentiation, and c-fos gene expression in the female reproductive tract. Endocrinology. 1998;139:2741-7.

38. Allard P, Colaiacovo MP. Bisphenol A. In: Gupta RC, editor. Reproductive and developmental toxicology. USA: Elsevier; 2011. p. 673-86.

39. Mendoza-Rodriguez CA, Garcia-Guzman M, Baranda-Avila N, Morimoto S, Perrot-Applanat M, Cerbon M. Administration of bisphenol a to dams during perinatal period modifies molecular and morphological reproductive parameters of the offspring. Reprod Toxicol. 2011;31:77-183.

40. Schonfelder G, Wittfoht W, Hopp H, Talsness CE, Paul M, Chahoud I. Parent bisphenol a accumulation in the human maternal-fetal-placental unit. Environ Health Perspect. 2002;110:703-7.

41. Kato H, Ota T, Furuhashi T, Ohta Y, Iguchi T. Changes in reproductive organs of female rats treated with bisphenol a during the neonatal period. Reprod Toxicol. 2003;17:283-8.

42. Newbold RR, Jefferson WN, Padilla-Banks E. Long-term adverse effects of neonatal exposure to bisphenol a on the murine female reproductive tract. Reprod Toxicol. 2007;24:253-8.

43. Zhou WJ, Liu J, Liao L, Han S. Effect of bisphenol a on steroid hormone production in rat ovarian theca-interstitial and granulosa cells. Mol Cell Endocrinol. 2008:283:12-8.
44. Vigezzi L, Bosquiazzo VL, Kass L, Ramos JG, Toro MM, Luque EH. Developmental exposure to bisphenol a alters the differentiation and functional response of the adult rat uterus to estrogen treatment. Reprod Toxicol. 2015:52:83-92.

45. Ashby J. Problems associated with the recognition and confirmation of low dose endocrine toxicities. Nonlinearily Biol Toxicol Med. 2003;1:439-53.

46. Rodriguez HA, Santambrosio N, Santamaria CG, Munoz-de-Toro M, Luque $\mathrm{EH}$. Eonatal exposure to bisphenol a reduces the pool of primordial follicles in the rat ovary. Reprod Toxicol. 2010;30:550-7.

47. Adewale HB, Jefferson WN, Newbold RR, Patisaul HB. Neonatal bisphenolAexposure alters rat reproductive development and ovarian morphology without impairing activation of gonadotropin-releasing hormone neurons. Biol Reprod. 2009;81:690-9.

48. Fernandez M, Bianchi M, Lux-Lantos V, Libertun C. Neonatal exposure to bisphenol a alters reproductive parameters and gonadotropin releasing hormone signaling in female rats. Environ Health Perspect. 2009;117:757-62.

49. Nishima K, Tanaka S, Sakamoto SH, Kuwahara S, Ohno T, Kitajima S. Populations of follicles in F344/N rats during aging. Reprod Biol. 2013;13:145-9.

50. Chevallet WME, Luche S, Van Dorsselaer A, Leize-Wagner E, Rabilloud T. Regeneration of peroxiredoxins during recovery after oxidative stress: only some overoxidized peroxiredoxins can be reduced during recovery after oxidative stress. Biol Chem. 2003;278:37146-53.

\section{Ready to submit your research? Choose BMC and benefit from:}

- fast, convenient online submission

- thorough peer review by experienced researchers in your field

- rapid publication on acceptance

- support for research data, including large and complex data types

- gold Open Access which fosters wider collaboration and increased citations

- maximum visibility for your research: over $100 \mathrm{M}$ website views per year

At BMC, research is always in progress.

Learn more biomedcentral.com/submissions 